\title{
Swami Vivekananda: Revival and reform in the making of Hinduism
}

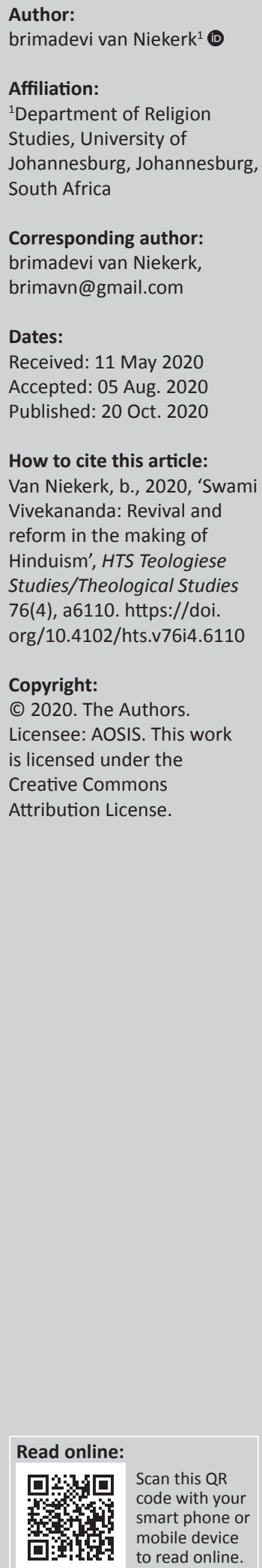

The importance of the life and teachings of Swami Vivekananda can never be overestimated by contemporary Hindus; the numerous Ramakrishna centres around the world bear testimony to his abiding influence even 127 years after his address to the Parliament of World Religions in 1893. Vivekananda symbolises a Hinduism that has been able to assert its sovereignty not just over the intolerable and very parochial missionary attitudes of Christianity in the 19th century, but his notion of universal Hinduism took root amongst the people of the world and thus positioned itself in the pantheon of World Religions. This article draws on Ninian Smart's notion of neofoundationalism to show how a series of reformers, culminating with Vivekananda, reach into the past to reconstruct and revive Hinduism. I argue that the success of Vivekananda was because of his particular version of Vedanta, which he first made accessible to the West at the Parliament of World Religions. I conclude that had it not been for Vivekananda's message of universalism, Hinduism would not have entered the World Religion stage at the end of the 19th century and that India would not have regained its national pride and self-consciousness.

Contribution: This study draws on Ninian Smart's notion of neofoundationalism to demonstrate how reformers reach into the past to reconstruct and revitalise Hinduism. And how through the particular success of Vivekananda, Hinduism is lifted from its narrow sociocultural moorings and placed among the pantheon of world religions.

Keywords: Swami Vivekananda; world religions; Hinduism; Parliament of World Religions; universalism; religion studies; neofoundationalism; reform.

\section{Introduction}

The Parliament of World Religions, in the History of Religions, was a convergence of paths and ideas of different cultures and religious persuasions from East to West. There were many speakers from the East ${ }^{1}$, but it is true that Swami Vivekananda is persistently recollected as the most prominent speaker at the inaugural Parliament held in Chicago in 1893. In this article, I examine the effectiveness of revival and reform, and how new elements, both in India and in America - an entirely different sociocultural system of beliefs and practices - are introduced. I look at three major revivals in India, the Brahmo Samaj, the Arya Samaj and end with the Ramakrishna Movement. How was an Indian, and in particular Hindu, identity in India being re-formulated? This article attempts in a small way to show how India responded to and dealt with revolutionary changes, and how this had consequences for its worldview. Most religions - but perhaps not all religions, especially in the remote spots of the world - have undergone western and modern influences.

And reform happens when, in response to foreign influence and criticism, a re-formation precipitates change, usually from within, to improve conditions.

The word reform from the Latin re means back, again, and formare, to form, that is, to put together: to restore, reconstruct or rebuild. I draw on Ninian Smart's (1998:407-408) concept of neofoundationalism as a framework to understand the strategies of reformers who reach back to the past as a re-orientation to the historical beginnings of a religion in the act of reform. So, for example, if one is working with Hinduism, a modern western-educated Hindu will draw on ancient motifs and philosophies and quote texts 3000 years old but will cast the faith in laws, which are fitting to the seminal period of the nineteenth and 20th century's thoughts and struggles. These re-formations, of course, have many implications. Whilst changes occur to protect and preserve the essence of a particular society for the future, it may mean deviations from an assumed faith because of the social and political changes within a society which could lead to ritual, ethical, doctrinal and philosophical changes. In the case of India, the distortion of, and demeaning 1.The other representatives speaking for Hinduism or who were from India were: Manilal N. D'vivedi, Protab Chunder Mozoomdar, the
then leader of the Brahmo Samaj, Vrichand A. Gandhi, Dharmapala, Miss Jeanne Sorabji (a Parsee who on the first day of the Parliament confessed that her father had converted to Christianity), and Professor C.N. Chakravati (ed. Barrows 1893, vol. 1:65-66). 
attitudes towards its teachings and practices by the colonisers, and the move towards modernity, have stirred the notion of reform and reconstruction as a means to developing its selfconsciousness. The result of reformation and revival was the admission of Hinduism into the pantheon of World Religions. To become a World Religion, a religion must be able to do a few things: religion should be able to emancipate itself; it must develop a universal message; it must own a doctrine of salvation that is unequivocal and accessible to its potential adherents; it must be literate; it must possess a collection of sacred scripture that is translatable into different languages; it must have a class of interpreters who can act as missionaries and above all, it must transcend cultural boundaries (Fitzgerald 1990:104)

And perhaps the greatest challenge for Vivekananda at the Parliament was how to take Hinduism out of its sociocultural moorings and make it universally relevant. And at the end of the 19th century all arguments and counterarguments about what constituted authentic Hinduism had been conclusively brought together by Vivekananda in his opening address. For in his proclamation, Hinduism was no longer a discrete system bounded by a singular sociocultural unit for a particular time and place, but it had opened to all who wanted it.

\section{India: Background}

The modern period in India is marked by the year 1750 when the British had laid claim to the whole of India, through a unique series of circumstances, establishing its authority over hundreds of millions of people. The burgeoning presence of Europeans and de-industrialisation, amongst other factors, led to the fragmentation of and the ultimate decline of the Mughal Empire. This pre-modern empire gave South Asia relative peace and stability during a large part of the 17th century, which was important for economic expansion. Under the influence of modern European civilisation, India's own civilisation and culture was at a low point. Whilst the notion of nation and nationalism - a product of British rule - may have had a positive effect by creating a geographical unity under the auspices of a common administration and cemented by a common language, English, nationalism was not understood within the framework of its pluralism and diversity. India had many separatist elements such as conflicts between the religions, ethnic and religious diversity, a variety of dialects and languages, social cleavages, and its general lack of progress towards modernity.

India may have been given the political unification it had lacked for centuries, but a cultural esprit de corps and its selfconsciousness as a nation were missing.

Technoscience and colonialism are inextricably linked, and whilst these may have regenerative images of development and utilitarian aspects, there are negative consequences as well. Under colonial rule, India retrogressed; there were no new cultural and philosophical developments, indigenous arts languished, under the sway of a totally different civilisation all creativity suffered and there was an uncritical acceptance of all things Western by the educated classes. This consequently engendered a feeling of contempt for things of indigenous origin. Some Indians viewed their ancient customs and traditions as outmoded, whilst others held on to their traditional ideas, resisting Western influences. However, India's exposure to Western science, literature and history, despite its cultural biases and disadvantages, brought a new awareness and expansion to the Indian mind. Many traditional practices and conventions such as child marriages, enforced widowhood, untouchability, the caste system, prohibition on travel, amongst others, began to lose hold. It is also important to note, as Armstrong (2014:262) said, that the Hindu, Sikh and Muslim communities at the time competed for favours, resources and political influence from their colonial administrators. And (Armstrong 2014) stated:

$[T]$ heir leaders discovered that the British were more receptive to their ideas if they believed that they represented a larger group, and realised that in order to prosper under colonial rule they would have to adapt to the Western understanding of religion. So new reform movements tended to adopt contemporaneous Protestant norms in a way that distorted these traditions. (p. 262)

It was in this zeitgeist that a renewal of thinking would appear through a series of reformers. And although these reformers were influenced by Western education and thought, they still clung to the linguistic, cultural and religious endowments of the motherland and would stoke India's pride more than nationalism did - at that time, anyway.

\section{The reformers}

It was in Bengal, the seat of the East India Company's power, at the beginning of the 19th century, where the first renovation of Hindu society began with Raja Rammohan Roy (1774-1833). Roy's intention in the sphere of religious reform was to return to the religion of their Indian ancestors. Consequently, he based his authority on the Upanishads and the Brahma Sutras as the authoritative texts of Hinduism. Notable members in the leadership of his society included, amongst others, Debendranath Tagore and Keshab Chandra Sen. Although Roy was born into an orthodox Brahmin family, he was greatly influenced by the ethical systems of Islam and Christianity and the concept of monotheism (Gupta 1942:52). His exposure to these philosophical ideas therefore made him critical of the polytheism in Hinduism; he published these criticisms in a book in Persian. The influence of Unitarian missionaries in Calcutta had an effect on the way in which he interpreted the Upanishads (Smart 1998:406). But what makes Roy's work important was his involvement in the abolition of sati, and in pointing out that polygamy was unscriptural, thereby making it an unacceptable practice (Kruger, Lubbe \& Steyn 2009:91). The appeal of the Roy's Brahmo Samaj was limited: it did not take hold amongst those who had a deep devotion to deities, nor did his abstract ideas take root amongst the Brahmins, whose primary concern was the preservation of ritual purity (Flood 1996:254). 
It is easy to look back at Roy's ideas and see them as parochial and limited to a very specific context within Indian society, but it is worth noting that his early revivalism brought out some classical ideas and models that might have otherwise been swept away. And his efforts in exposing and dealing with some of the social ills of that society must be acknowledged. Furthermore, this early revival demonstrates that religious regeneration precipitated the abolition of sati and reduced polygamy.

The second revival began with Swami Dayananda Saraswati, who founded the Arya Samaj in 1875. In contrast to Roy, Dayananda was a guru, a Sanskrit scholar and a sannyasi, who attempted to return to Vedic orthodoxy. Dayananda did not want to be influenced by other religions the way Roy was. For Dayananda, only the Vedic hymns were seen as true texts. The Brahmanas and the Upanishads, which were seen as later accretions to Hindu philosophy and theology, were fallacious and sectarian and therefore to be abandoned (Smart 1998:407). Having renounced the Brahmins and disposed of their services, Dayananda opened the study of scripture to women and outcastes, thus instituting early notions of an egalitarian society. His principle idea was a strict monotheism and an iconoclasm that did not appeal to many Hindus who wanted to maintain their colourful practices and multiplicity of gods. This was probably Dayananda's weakness; he did not consider the religious pluralism in India and what this meant for nationhood. Furthermore, the Arya Samaj was (Armstrong 2014):

$[A] n$ extremely reductive form of 'Hinduism' since the Vedic tradition had long been the faith of a small elite and very few people were able to understand ancient Sanskrit. It thus tended to appeal only to the educated classes. (p. 262)

The success of the Samaj, it would appear, was mainly in the Indian diasporas in places such as South Africa and Fiji where Indians worked as indentured labourers. Despite the Samaj's relatively short reign in India, important precedents were established, which show that these revivals did not take place against a background of complete cultural decay, but that they forged developments 'reaching back to their foundations' (Smart 1998:408), which prepared the way for later achievements that were to come in the late 19th century.

Towards the end of the 19th century there appears to be a culmination of a series of strands from the earlier plots, not breaking with the past but re-formulating trends for a new era in the religious and cultural life of India, and thus beginning the third in the series of revivals. It was through the pluralist perspective of Ramakrishna, which was followed through by his disciple, Swami Vivekananda, that modern Hindu ideology and philosophy would appear.

Ramakrishna was born to a Brahmin Vaishnava family in Bengal. After the death of his father, Ramakrishna went to Calcutta to assist his brother with the management of a new temple dedicated to the Mother Goddess Kali. At the Dakshineshwar temple, all the main threads of Bengali and bhakti were present such as Siva, Radha and Krishna. After the death of his brother, Ramakrishna acceded to the priestly functions at the temple. Ramakrishna became the priest of the Mother Goddess and he was absorbed in the ecstasies relating to her. His religious practices and worldview contained elements of Bhakti, Tantra and Vedanta. Having reached the highest state in non-dual meditation, the independent existence of the Mother and God disappeared. His meditation experiments were extended to include Jesus Christ and Allah. Ramakrishna claimed that his intense visions of God were similar in nature to his Hindu experiences. This convinced him of the ultimate unity of all religions. The middle classes of Calcutta were convinced. Furthermore, by presenting the Hindu heritage positively, he averted the decisions of those who were considering converting to Christianity. Amongst the people who visited Ramakrishna at the temple was the young Narendranath Datta. This young man was impressed enough to become a renunciate eventually under the name Vivekananda, but only after a succession of events in his own life. The making of Swami Vivekananda and his monastic path is beyond the scope of this article.

The essence of Ramakrishna's teachings of inclusiveness may be summed up in the following Vedic phrase: Truth is one; only it is called by different names. His teachings of Vedanta would translate into its greater use not just for India as a nation but for the whole world. Vedanta in practical terms meant: the elevation of the masses through education; ending India's cultural isolation; taking Vedanta out of obscurity and transmitting it to all people of the world regardless of creed, colour and caste and the practical application of Vedantic truths to all areas of life (Kruger et al. 2009:93). Although Ramakrishna was removed from the issues of modernism and national independence, it was Vivekananda, under his tutelage, who endeavoured to translate his master's teachings into concrete measures for the reformation of Hinduism and of Hindu society.

\section{Shankara's Advaita Vedanta and Ramanuja's Vishistha Advaita}

There were numerous philosophical and theological positions that would influence Vivekananda's own practice and teachings, but the two most notable Indian thinkers were Shankara and Ramanuja. I have used Stevenson and Haberman (1998:56-65), Flood (1996:239-243) and Kruger et al. (2009:81-83) in the composition of this broad summary of the two philosophical positions.

Shankara was an 8th century Indian philosopher and his position constitutes one of the most popular justifications for the act of religious renunciation. Shankara was the first Indian philosopher to address some of the very pressing questions regarding Brahman and the relationship between the ultimate reality and the world of multiplicity we experience through our senses. His is a philosophy of unity that devalues all diversity. For Shankara, Brahman is the only truth. The world experienced through our senses is not Brahman and ultimately not real. 
Ramanuja, a theologian and philosopher, lived possibly between the 11th and 12thcenturies. He was the chief interpreter of Vedanta for the south Indian devotional movement known as Shri Vaishnavism. His philosophical system is classified as Vishistha Advaita (Non-Dualism of the Differentiated) as it takes differentiated things to be real and understands them to be attributes of a non-dual reality. His theological position, therefore, was diametrically opposed to that of Shankara's. For many Vaishnava Hindus, the worship of God in the form of Lord Vishnu is the personal nature of the divine and an ultimate attitude, not an illusion to be transcended. Whilst both these philosophers accept the Upanishadic postulation that Brahman is the sole reality, for Ramanuja, Brahman means God who is equipped with multiple qualities.

However, Shankara does make a compromise and concedes to the idea of devotion (bhakti) to the personal Lord (Isvara), but only as a lower level of knowledge. Brahman, in its timeless essence as identical with the self, is beyond all predicates and qualities (nirguna), but in its temporal mode as the Lord it has attributes (saguna), and so can be approached through devotion as an object of consciousness. To see the absolute as the Lord is to maintain a distinction between self and absolute, which is to retain a remnant of ignorance that must be finally transcended; if reality is one, all distinction must be illusory. Many of the devotional theologians within Hinduism remark that they do not want to become sugar (Shankara's goal); instead, they want the blissful experience of tasting sugar (Ramanuja's goal).

For Shankara, the highest spiritual path consists of a meditative practice designed to lead one to the perceptive realisation that 'I am Brahman'. A salient precondition for this practice, however, is to remove oneself from the quotidian practices of life that affect the senses and move towards world renunciation.

Ramanuja, on the other hand, has a more positive view of the world and insists that one should engage in activities according to one's own life situation; renouncing the world is simply another attempt to establish control and does not lead to a state of perfect happiness. Instead, Ramanuja advises complete surrender to God, for only then comes the freedom to enjoy the splendour of the world. So, although renouncer traditions may be found all over India, bhakti devotion in temples and home altars dominate Hindu piety.

It was the synthesis of these two philosophical systems, together with his master, Ramakrishna, that influenced Vivekananda's thinking.

\section{America: Background}

The Great Awakening that broke out in the middle of the 18th century brought with it new religious fervour that revitalised American piety, changing it from ritual and ceremony to personal religion. This wave of religious enthusiasm amongst Protestants swept the colonies in the 1730s and 1740s, leaving a permanent impression on American religion. What The Great Awakening shows is that religion, 'instead of being an obstacle to progress and democracy, could be a positive force for modernisation' (Armstrong 2014:243). What's more is that it was America's first mass movement that gave ordinary people their first experience of something that extended to the whole country and that would change the tide of history (Armstrong 2014:245). Furthermore, the theological innovations in this period extended to include the people's concerns to the issue of slavery whilst challenging the establishment.

Towards the end of the 18th century a new wave of revivals, known as the Second Great Awakening, began with the ordinary people who campaigned for a more 'democratic and Bible-based America' (Armstrong 2014:249). It was an age of mass rallies, huge tent campaigns and Gospel songs that drove crowds to euphoria. Emotions and feelings, as opposed to dry intellectual discourse, became part of the new religious practice. Whilst the elite looked at the revival as backward, it was in effect 'a Protestant version of the Enlightenment' which gave the revivalists the beginnings of the modern ideals of democracy, equality, freedom of speech and independence, in a characteristic mode of expression that uneducated people could claim as their own (Armstrong 2014:249).

The spirit of what began with the downtrodden in America would continue in the form of evangelical Christianity amongst the middle classes. By the mid-19th century, evangelicalism had become the dominant faith in America. In the second half of the 19th century the process of settlement and industrialisation speeded up. Large numbers of immigrants, mainly Catholic and Jew, descended on predominantly Protestant America (Smart 1998:372). Adjustments had to be made on both sides for these immigrants to be successfully integrated into their new religious and social circumstances and surroundings.

This period also witnessed the development of Black religion, enhanced by the migration of many people from the South to the industrial north. Their growing awareness of social and political injustices led to African Christianity becoming charged with the struggle for justice (Smart 1998:373-374).

From academic quarters, the 18th and 19th century discourse on religion was ostensibly still concerned with the amassing of conjectural suppositions relating to the origins and development of religion (Masuzawa 2005:12). It was, nevertheless, during the latter half of the 19th century that interest in the religions of the world became extensive in America. The momentum that began to establish itself in a number of disciplines, namely theology, philology, history and ethnology and whose works had become the basis of comparative studies (Masuzawa 2005:265). From 1867, various chairs in these respective disciplines were created to advance the study in comparative religion at various universities across the United States and which included, 
amongst others, Harvard, New York, Cornell, Chicago and Princeton. Some of the pioneering academics who held these positions were the likes of James Freeman Clarke, Samuel Johnson, James Moffat, William Dwight Whitney and George Stephen Goodspeed. These scholars began publishing works that reflected a diversity of approach and a consciousness about the study of religions hitherto disregarded in North America. The themes that dominated their discussions related to the religious zeitgeist of the time, which showed that they were taking other religions seriously and at the same time moving away from notions that Protestantism, Catholicism and Judaism were the only religious discourses that mattered.

Whilst official positions were established and academic scholarship thrived under the banner of world religions, what was missing was the actual contact with those other religions. For, arguably, the study of religious pluralism cannot be restricted only to the facts or abstract concepts regarding other religious systems and their doctrinal teachings (Singh 2005:64). What was needed then was the praxis and out-workings of these academic pursuits to be witnessed firsthand. However, early 19th century American history had been a time of drastic disruption, which was most discernible in the area of religion. Hutchinson (2003:19) had argued that there were unparalleled demographic changes in this era, and the numerical superiority of Protestant Christianity was greatly reduced. Furthermore, what made the religious changes in that era so deeply disturbing was not merely that the American demographics had changed, but that it differed greatly from what had possibly existed in the colonial period. The colonials, apparently, 'had thought of their society and culture as diverse', but it had on the whole remained 'broadly homogenous for more than two centuries' (Hutchinson 2003:19-20). What the encounter with diverse cultures reflected was that discourses about 'religious diversity' and 'religious pluralism' were changing in American society (Hutchinson 2003:112).

The major themes emerging in American religious history by the end of the 19th century related largely to the notions of intolerance, diversity and pluralism, which were resolvable only through contact and dialogue with other religions. And as Barrows (1893:5-6), the chairman of the Parliament of World Religions committee noted on the importance of the Parliament: '... there has been much dissonance between the various religions and that has alienated many people in history. The modern idea was towards unity'.

\section{Vivekananda goes to America}

In order to understand perhaps why Vivekananda's message was so effective, I show why the other speakers at the Parliament may not have had the same appeal by drawing on some aspects of an article presented by one of the Hindu delegates, D'vivedi. But before presenting D'vivedi, I present a brief illustration from the data collected in participant observation of Hinduism that was presented at the
Parliament from the perspective of a missionary who was based in India.

Perhaps not all accounts by missionaries, in the late 19th century, of their experiences and interpretations of their work in the colonies amongst other religions may be viewed as derogatory and disrespectful. Thomas Ebenezer Slater was an exception. As a missionary from the London Missionary Society, he had begun his career in Calcutta and then continued in Madras. At the time of the Parliament he worked in Bangalore. His article, 'Concession to native ideas, having special reference to Hinduism' point out that Hindus (Barrows 1893):
... [B]y instinct and tradition, are the most religious people in the world. They are born religiously, they eat, bathe, shave and write religiously, they die and are cremated or buried religiously, and for years afterward they are devoutly remembered religiously. They will not take a house or a shop or office, they will not go on a journey or engage in any enterprise, without some religious observance. We thus appeal in our missionary effort to a deeply religious nature; we sow the gospel seed in a religious soil. (p. 456)

His understanding of the religious habits of Indian people, correct in its details, his appraisal of Hinduism's plurality, inclusiveness, its heterogeneous nature, diversity and its wide metaphysical philosophies shows that he went deeper than simply casting aspersions on what he observed. The religious paradigms of institutionalised institution, homogeneity and community, and a single definitive religious book, the notion of a monotheistic God, amongst other things, is highly unsatisfactory in the study of Hinduism, especially if it is viewed from Christian and Western categories in the way we study religion. Perhaps what Slater finds difficult is the idea that a Hindu can be a Hindu regardless of whether her personal views lean towards monotheism, monism, polytheism or atheism. And hence his observation of a foreign system that betrays those inherited categories he is familiar with (Barrows 1893):

$[W]$ hat is styled as 'Hinduism' is a vague eclecticism, the sum total of several shades of belief, of divergent systems, of various types and characters in the outward life, each of which at one time or another calls itself Hinduism, but which, bears little resemblance to other beliefs. Every phase of religious thought and philosophic speculation has been represented in India. Some of the Hindu doctrines are theistic, some atheistic and materialistic, others pantheistic - the extreme development of idealism. Some of the sects hold that salvation is obtained by practicing austerities and by self-devotion and prayer; some that faith and love (bhakti) form the ruling principle; others that sacrificial observances are the only means. Some teach the doctrine of predestination: others that of free grace. (p. 456)

\section{The Reverend Slater admits that}

$[I] \mathrm{t}$ is hard for foreigners to understand the habits of thought and life that prevail in a strange country, as well as all the changes and sacrifices that conversion entails; and, with our brusque, matter-of-fact Western instincts, and our lack of spiritual philosophic insight, we too often go forth denouncing the 
traditions and worship of the people, and, in so doing, are apt, with our heavy heels, to trample on beliefs and sentiments that have a deep and sacred root. (Barrows 1893:456-457)

Note his description of the foreign land as 'strange' emphasising the phenomena he had seen as odd and peculiar. Despite the fact that Slater is trying to convert people, he has a deep respect for their beliefs and is critical of the westerner's too easy dismissal of them. A little irony is, given the fact that he was a missionary and still doesn't seem to have the average condescending view of the 'other'. Regardless, the Reverend Slater returns to his belief and concludes that the purpose of religion is in the Bible alone.

Manilal N. D'vivedi was a Justice of the Peace of the town of Nadiad in Maharashtra and a member of the Philosophical Society of Bombay, who also addressed the Parliament on that occasion (Barrows 1893:65-66). D'vivedi's opening strategy took the form of addressing the Biblical religions and their irrational and unfounded use of a limited chronology in their histories and revelations, whilst showing that for the Hindu time is not measured in the same way except through the cycles of yugas. According to Smart (1998:353), the use of history in a modern manner to investigate the past, rather than just tell a story, inevitably began to raise questions about the historicity of the Bible, whereas the formation of evolutionary theory was amongst the factors that brought doubt to the understanding of traditional cosmology (Smart 1998:353). This is what D'vivedi argued (Barrows 1893):

$[W]$ hereas the Indian religion claims exorbitant antiquity for its teachings, the tendency of Christian writers has been to cramp everything within the narrow period of 6000 years. But for the numerous vagaries and fanciful theories these extremes give birth to, this point has no interest for us at the present moment. With rapid advances made by physical science in the West, numerous testimonies have been unearthed to show the untenableness of biblical chronology, and it would be safe to hold the mind in mental suspense in regard to this matter. (p. 316)

What D'vivedi attempted in his address was to present his audience with details relating to the various texts found in Hinduism and a discussion on semantics. His other strategy, as an attack on the biblical faiths, was to use Biblical chronology as irrational and unfounded. The main point of his argument was to persuade his western audience, who he assumed were not very well informed about Hinduism, that he was going to correct their misconceptions. And as such his article was long and excessively concerned with details about the various texts, semantics, doctrines and the caste system. And then to end, the notion of universality in religion is raised about the possibility of articulating the principles of a universal religion without adhering to any religion in particular (Barrows 1893):

$[H]$ aving ascertained the general and particular scope and meaning of Hinduism, I would ask you, gentlemen of this august Parliament, whether there is not in Hinduism material sufficient to allow of its being brought in contact with the other great religions of the world, by subsuming them all under one common genus. In other words, is it not possible to enunciate a few principles of universal religion which every man who professes to be religious must accept apart from his being a Hindu, or a Buddhist, a Mohammedan or a Parsee, a Christian or a Jew? (p. 331)

Then came the '... eloquent monk Vivekananda of Bombay, clad in gorgeous red apparel, his bronzed face surmounted with a huge turban of yellow' (Barrows 1893:62), who addressed the audience. What did Vivekananda (1977, vol. 1:5) say that gave him such a warm reception from the moment he uttered his now famous opening lines: 'Sisters and Brothers of America ...'. At first these words appear to be a common-place greeting to fellow religious travellers. But on closer inspection it reveals much more: in these words are the embodiment of a whole new metaphysic; in it the unity of religion; in it the relationship between the divine and the different parts of the cosmos; in it immanence; in it is the notion of transcendence; the collapse of geographical spaces; the strategic effort to re-appropriate history and remove the dualistic 'us' versus 'them'. In these words are the seeds of the making of Hinduism as a world religion.

Drawing on Fitzgerald's (1990) dimensions of what constitutes a world religion, mentioned above, I show how Vivekananda presents a Hinduism that addresses all the major concerns regarding Hinduism's universal relevance, its doctrine of salvation, its sacred texts, in a way that allows it to transcend all cultural boundaries.

Amongst various religious groups, to call someone a 'sister' or 'brother' means to address that person as a 'fellow believer' or fellow religious traveller. There is an element of family and kinship insofar as the religion of a group means that it holds similar views, which are no doubt attached to the same God.

Vivekananda's address would suggest a connection between the speaker and the audience that invariably joins them in a way that is suggestive of inclusivity and solidarity. And so, when Vivekananda addressed his audience as sisters and brothers of America, he had in fact inaugurated his notion of universal acceptance. What Vivekananda was announcing at this point was oneness and unity - the core of his metaphysical beliefs. And if Vivekananda, like his master, believed that the nature of God in Islam and Christianity was similar, then of course the people who were gathered at this august assembly were indeed his sisters and brothers. This then does not only suggest the unity of all religions, but that all religions are accepted as true (Vivekananda 1977, vol. 1:3). And in this simple act of his opening address, Vivekananda (1977, vol. 1) removed Hinduism from its cultural moorings and extended it to the world, which is so aptly captured in his second address:

[I] am a Hindu. I am sitting in my own little well and thinking that the whole world is my little well. The Christian sits in his well and thinks the whole world is his well. The Mohammedan sits in his little well and thinks that is the whole world. I have to 
thank you of [sic] America for the great attempt you are making to break down barriers of this little world of ours, and hope that, in the future, the Lord will help you accomplish your purpose. (p. 5)

On the nature of the soul, reincarnation and general Hindu soteriology, Vivekananda (1977, vol. 1) refrains from delving into abstract concepts that are abstruse, in the way D'vivedi had done in his presentation, but rather, he offers the explanation through the use of metaphor which comes across with the gentleness of a mystical master:

$[W]$ ell, then, the human soul is eternal and immortal, perfect and infinite, and death means only a change of centre from one body to another. The present is determined by our past actions, and the future by the present. The soul will go on evolving up or reverting back from birth to birth and death to death. But here is another question: Is man a tiny boat in a tempest, raised one moment on the foamy crest of a billow and dashed down into a yawning chasm the next, rolling to and fro at the mercy of good and bad actions - a powerless, helpless wreck in an everraging, ever-rushing, uncompromising current of cause and effect ... (p. 10)

Vivekananda offers the Vedas as the foundational text of the Hindus, not in a way that is typical of what is to be expected by the biblical traditions - or Islam for that matter, but as a point of centring for Hindus. It betrays the classic idea of what a religious text should be, that is, it has no beginning and no end, presenting a God that is ever-present in the evolution of creation (Vivekananda 1977, vol. 1):

$[T]$ he Hindus have received their religion through revelation, the Vedas. They hold that the Vedas are without beginning and without end. It may sound ludicrous to this audience, how a book can be without beginning or end. But by Vedas no books are meant. They mean the accumulated treasury of spiritual laws discovered by different persons in different times. Just as the law of gravitation existed before its discovery, and would exist if all humanity forgot it, so it is with the laws that govern the spiritual world. (p. 6)

\section{Conclusion}

I set out to show that during the latter half of the 19th century, India was ready to take on the challenges of regaining its identity in a colonially demarcated space. I have shown that how the reforms initiated by Raja Rammohan Roy and Swami Dayananda, although limited in their appeal, nevertheless, in reaching back to the past, brought out ancient classical models that might otherwise have been swept away, and established important precedents. It was Vivekananda, I have argued, who, having been influenced by the pluralist perspectives and exclusivist philosophy of his master, as well as the philosophical and theological positions of Shankara and Ramanuja, produced a new metaphysic of Hinduism, which was a success both in India and abroad. For India, it meant the restoration of its national pride and unity and the acceptance of its religion as substantive and true. For the West, which was also at that time ready to receive the seed of
Hinduism, it meant an offering of Hinduism that was universal because it could be lifted out of its very particular sociocultural moorings and take its place amongst all people as a world religion; no longer was Hinduism confined to a particular place for a particular people. Furthermore, Vivekananda's theological posture that all religions lead to the same goal was not only a unique form of universalism, but one that would include all other religions as well. This was the breadth of his vision.

The lasting effects of Vivekananda's reappraised Hinduism, which he presented to the World Parliament of Religions in 1893 to such powerful effect, paved the way for the resurgence of religion and spirituality that prevailed during the latter half of the 20th century beginning with the 1960s counter culture. More research may be attempted in this direction.

\section{Acknowledgements Competing interests}

The author has declared that no competing interest exists.

\section{Authors' contributions}

I declare that I am the sole author of this research article.

\section{Ethical consideration}

This article followed all ethical standards for research without direct contact with human or animal subjects.

\section{Funding information}

This research received no specific grant from any funding agency in the public, commercial or not-for-profit sectors.

\section{Data availability statement}

Data sharing is not applicable to this article as no new data were created or analysed in this study.

\section{Disclaimer}

The views and opinions expressed in this article are those of the author and do not necessarily reflect the official policy or position of any affiliated agency of the author.

\section{References}

Armstrong, K., 2014, Fields of blood: Religion and the history of violence, The Bodley Head, London.

Barrows, J.H., 1893, The world's parliament of religions, The Parliament Publishing Company, Chicago, IL.

Fitzgerald, T., 1990, 'Hinduism and the “World Religion" fallacy', Religion 20(2), 101-118. https://doi.org/10.1016/0048-721X(90)90099-R

Flood, G., 1996, An introduction to Hinduism, Cambridge University Press, Cambridge.

Gupta, M., 1942, The gospel of Sri Ramakrishna, translated from the Bengali by Swami Nikhilananda, Reproduced from the webpage of Ramakrishna Math and Ramakrishna Mission, viewed 7 May 2020, from http://www.belurmath.org/ gospel/index.htm.

Hutchinson, W.R., 2003, Religious pluralism in America: The contentious history of a founding ideal, Yale University Press, New Haven, CT. 
Kruger, J.S., Lubbe, G.J.A. \& Steyn, H.C. 2009, The human search for meaning: A multireligion introduction to the religions of humankind, Van Schaik Publishers, multireligior
Pretoria.

Masuzawa, T., 2005, The invention of world religion, or how European universalism was preserve in the language of pluralism, The University of Chicago Press, Chicago, IL.

Naicker, S., 2016, 'Analysis of water-related metaphors within the theme of religious harmony in Swami Vivekananda's complete works', HTS Teologiese Studies/ Theological Studies 72(4), a3431. https://doi.org/10.4102/hts.v72i4.3431
Singh, D., 2005, 'Sikhism and religious pluralism', in P.F. Knitter (ed.) The myth of religious superiority: A multifaith exploration, pp. 62-72, Orbis Books, Maryknoll, New York, NY.

Smart, N., 1998, The world's religions, 2nd edn., Cambridge University Press, Cambridge.

Stevenson, L. \& Haberman, D.L., 1998, Ten theories of human nature, Oxford University Press, Oxford.

Vivekananda, S., 1977, The complete works of Swami Vivekananda, vols. 1-9, Mayavati Press, Calcutta. 